\title{
Nilai-nilai kearifan lokal pada unsur naratif dan sinematik film Jelita Sejuba
}

\author{
Dasrun Hidayat $^{1}$, Zainur Rosidah ${ }^{2}$, Maya Retnasary ${ }^{3}$, dan Mahardiansyah Suhadi ${ }^{4}$ \\ ${ }_{1,2,3,4}$ Universitas Bina Sarana Informatika, Bandung, Indonesia
}

\begin{abstract}
ABSTRAK
Jelita Sejuba merupakan film layar lebar yang mengangkat nilai-nilai kearifan lokal di Pulau Natuna. Dengan kreativitas yang tinggi, sutradara film mengemas dialog melalui narasi percintaan gaya anak muda Natuna. Hal yang menjadi filosofi film ini diproduksi dengan maksud memperkenalkan Natuna melalui unsur naratif dan sinematik film. Tujuannya adalah untuk mengetahui nilai-nilai kearifan lokal yang terdapat pada tiap simbol budaya pada film tersebut. Penelitian ini menggunakan studi kuasi-kualitatif deskriptif dengan paradigma post-positivistik. Melibatkan beberapa sineas, kritikus, dan penikmat film sebagai sumber data untuk memberikan jawaban atas beberapa pertanyaan wawancara. Hasil yang diperoleh bahwa nama Jelita merepresentasikan kecantikan dan keluhuran budi anak gadis Natuna. Kecantikan tersebut dianalogikan seperti kecantikan pulau Natuna yang disebut Sejuba. Analisis data penelitian juga memaparkan nilai-nilai kearifan lokal melalui unsur sinematik film, antara lain set lokasi dengan menggunakan latar belakang pulau Natuna meliputi rumah khas masyarakat Natuna yang terletak di pinggir pulau, keindahan bebatuan yang menjulang tinggi, dan pohon kelapa yang tumbuh di sepanjang pulau Natuna. Temuan nilai kearifan lokal lainnya yakni terkait dengan penggunaan bahasa Melayu di beberapa adegan film Jelita Sejuba. Nilai kearifan lokal juga dapat dirasakan ketika penonton dimanjakan dengan tata musik Melayu serta tata artistik daerah Natuna. Film Jelita Sejuba juga menampilkan makanan khas daerah Natuna yang digambarkan pada unsur naratif dan sinematik film.
\end{abstract}

Kata-kata Kunci: Film; kearifan lokal; naratif; pulau natuna; sinematik

\section{Local wisdom values in narrative and cinematic elements of Jelita Sejuba film}

\begin{abstract}
Jelita Sejuba is a big screen film that elevates the values of local wisdom on Natuna Island. With high creativity, the film director packed the dialogue through the narrative of young Natuna's romantic style. This is the philosophy of this film produced with the intention to introduce Natuna through the narrative and cinematic elements of the film. The aim is to find out the values of local wisdom contained in each cultural symbol in the film. This research uses a descriptive quasi-qualitative study with a post-positivist paradigm. Involving filmmakers, critics, and connoisseurs of films as a source of data to provide answers to several interview questions. The results obtained show that Jelita's name represents the beauty and nobility of Natuna's girls. The beauty is analogous to the beauty of the Natuna island called Sejuba. Analysis of the research data also explained the values of local wisdom through cinematic film elements, including the set of locations using the Natuna island as the background, including the typical Natuna houses located on the edge of the island. The beauty of the towering rocks, and coconut trees that grow along the Natuna island. Another finding of local wisdom values is related to the use of Malay in some scenes of the film Jelita Sejuba. The value of local wisdom can also be felt when the audience is spoiled with the Malay musical and artistic arrangements of the Natuna region. The film Jelita Sejuba also features Natuna regional typical food depicted in the narrative and cinematic elements of the film.
\end{abstract}

Keywords: Film; local wisdom; narrative; natuna island; cinematic

Korespondensi: Dr. Dasrun Hidayat, S.Sos., M.I.Kom. Universitas Bina Sarana Informatika, Jalan Sukalaksana Nomor 6 Antapani Bandung.Email: dasrun.dhy78@gmail.com 


\section{PENDAHULUAN}

Dunia perfilman saat ini mulai melirik nilainilai budaya sebagai bagian dari unsur produksi film seperti unsur naratif dan sinematik. Ide cerita tentang film bernuansa nilai budaya lokal yang digagas oleh para sineas tersebut selaras dengan kondisi Indonesia yang memiliki ragam nilai budaya sebagai kearifan lokal. Film yang mengandung muatan kearifan lokal-pun dapat dijadikan alat tangkal penetrasi kebudayaan asing yang tanpa disadari mendominasi pasar film Indonesia. Film bernuansa kearifan lokal juga sekaligus sebagai alat promosi budaya Indonesia di mata dunia. Film dengan konteks kearifan lokal seharusnya dapat menjadi potensi dalam berbagai bidang, misalnya membantu pemerintah memperkenalkan atau mengedukasi budaya yang belum dikenal luas-mengingat negara Indonesia merupakan negara kepulauan.

Film dengan konteks kearifan lokal sepertinya sudah menjadi salah satu pilihan para produsen dalam industri perfilman Indonesia. Hal ini terbukti ketika dalam kurun waktu tiga tahun ini saja ada sekitar empat film layar lebar dengan mengambil setting kearifan lokal sudah rilis yaitu Uang Panai Turah (2016), Sekala Niskala (2017), Marlina Si Pembunuh dalam Empat Babak (2017) dan Yowis Ben (2018). Diantara film-film tersebut, film Marlina Si Pembunuh dalam Empat Babak telah mendapatkan beberapa penghargaan, seperti piala citra untuk pemeran utama wanita terbaik dan Indonesia movie actors award untuk pemeran pendatang baru. Namun sayangnya meskipun film-film tersebut telah diakui, akan tetapi keberadaannya belum bisa bertahan lama jika dibandingkan dengan film tidak sejenis.

Ide cerita film dengan konteks nilai kearifan lokal memang masih memerlukan strategi khusus agar film tersebut dapat bertahan di masyarakat. Karenanya, penting untuk diketahui tentang bagaimana kearifan lokal dan lokalitas ditampilkan dalam layar film. Termasuk ide tentang unsur film meliputi proses naratif dan sinematik film yang menceritakan tentang nilai kearifan lokal. Sejatinya sutradara memiliki strategi dalam memadukan dua unsur utama tersebut agar keduanya tampil seimbang antara faktor inklusi dan eksklusi. Hal ini menjadi penting karena penonton akan menikmati sebuah tontonan yang menarik melalui ide kreatif sutradara film.

Kearifan lokal dapat dikatakan sebagai sesuatu yang berkaitan secara spesifik dengan budaya lokal dan mencerminkan cara hidup suatu masyarakat pada lokalitas tertentu. Artinya bahwa kearifan lokal tertanam pada budaya lokal masyarakat tertentu (Susilowati, Dhanang, \& Noor, 2014). Budaya lokal juga sering disebut budaya daerah yang biasanya digunakan untuk membedakan suatu budaya dari budaya nasional (Indonesia) dan budaya global. Budaya lokal adalah budaya yang dimiliki oleh masyarakat yang menempati lokalitas atau daerah tertentu yang berbeda dari budaya yang dimiliki oleh masyarakat yang berada di tempat yang lain (Susilowati, Dhanang, \& Noor, 2014). Kearifan lokal dapat pula menjadi ciri khas atau bahkan identitas budaya kelompok tertentu. Ragam budaya merepresentasikan bahwa Indonesia memiliki banyak nilai kearifan lokal.

Kearifan lokal merupakan salah satu unsur yang tidak dapat dilepaskan dari identitas bangsa Indonesia. Kearifan lokal dibentuk atas keyakinan terhadap nilai-nilai budaya. Bahkan dalam penelitian sebelumnya disebutkan bahwa kearifan lokal merupakan pedoman dalam bertindak dan sekaligus mencerminkan sistem keyakinan dan cara hidup suatu masyarakat tertentu (Hidayat, Kuswarno, Zubair, \& Hafiar, 2018). Sayangnya, nilai-nilai tersebut terkadang belum diketahui masyarakat secara luas. Nilai-nilai kearifan lokal benar-benar baru sebatas pengetahuan lokal yang semestinya diperkenalkan secara universal. Untuk itu, dibutuhkan pendekatan yang khas dalam memperkenalkan nilai-nilai budaya sebagai kearifan lokal.

Di antara pendekatan yang dinilai efektif dalam memperkenalkan nilai kearifan lokal adalah melalui produksi film. Produksi yang melibatkan nilai-nilai budaya di dalamnya menetapkan unsur-unsur naratif maupun unsur sinematik film. Pada dasarnya film yang mengambil latar atau setting budaya lokal secara otomatis nilai-nilai kearifan lokalnya akan terangkat baik dari aspek naratif maupun 
sinematik. Film Jelita Sejuba memiliki potensi sebagai film yang layak diapresiasi karena hasil produksinya mampu memperkenalkan salah satu kearifan lokal kepulauan terluar Indonesia yaitu Natuna.

Pembuatan film sebagai pendekatan dalam mengenalkan nilai kearifan lokal, selaras dengan fungsi film sebagai salah satu media komunikasi yang efektif. Film dinilai sebagai wadah dalam menyebarkan nilai-nilai, yakni mensosialisasikan nilai-nilai tertentu dalam suatu kelompok masyarakat (Saptya, Puspitasari, \& Indriani, 2018). Film juga dinilai sebagai sebuah proyek audio visual dengan berbagai unsur yang dapat digunakan sebagai alat mensosialisasikan identitas kelompok tertentu (Vajdovich, 2019). Film adalah deretan kata-kata yang dapat saja diperoleh dari novel, riwayat hidup, sandiwara radio, kisah nyata atau kisah rekaan, atau komik sebagai sumber penceritaan (Baksin, 2003). Film dalam konteks ini bekerja seperti bahasa yang memuat kodekode atau tanda-tanda yang berfungsi untuk memproduksi makna-makna (Noviani, 2011).

Film tidak hanya menjadi sebuah media dengan tujuan hiburan saja, namun secara tidak langsung menjadi alat komunikasi, penanaman nilai, propaganda, dan indoktrinasi. Dengan begitu film merupakan salah satu media dalam komunikasi massa. Film sebagai media massa mencoba merefleksikan realitas atau membentuk realitas. Film membantu akses informasi sehingga dapat dikonsumsi dengan mudah. Film sebagai media massa juga sangat berpengaruh terhadap pembentukan citra tentang suatu realitas (Munanjar, 2016).

Dalam memproduksi sebuah film ada dua unsur yang dapat membangun keutuhan film yakni unsur naratif dan sinematik. Setiap unsur pembentuk film tersebut tidak dapat membentuk film, jika hanya berdiri sendiri. Unsur naratif serupa materi yang akan diolah atau ide cerita film termasuk di dalamnya menentukan tokoh dan karakter. Sementara, unsur sinematik adalah cara untuk mengolah ide cerita tersebut menjadi gambar audiovisual (Pratista, 2008).

Untuk memadukan dua unsur film yakni naratif dan sinematik, maka diperlukan tahapan perencanaan yang baik. Perencanaan tersebut bagian dari strategi sutradara dalam memproduksi film. Banyak pendekatan dalam membangun strategi produksi film, diantaranya pendekatan perencanaan kerja public relations yang menekankan pada analisis situasi, penetapan nama program, jenis, tema serta eksekusi atau produksi (Pakaradena, Hafiar, Nugraha, 2018). Dalam produksi film, sineas dituntut untuk membuat perencanaan produksi meliputi dua unsur film yaitu naratif dan sinematik yang dikelola secara seimbang.

Film Jelita Sejuba yang disutradarai oleh Ray Nayoan merupakan salah satu film yang memenuhi perencanaan produksi yang baik. Film ini menggunakan latar belakang budaya Sejuba yaitu kondisi masyarakat pesisir pantai Natuna. Sejuba adalah kawasan pesisir pantai Natuna yang dipenuhi dengan batu-batu besar seperti Belitung. Kearifan lokal dalam film ini melekat melalui pakaian, tarian, ilustrasi musik, makanan tradisional dan penggunaan bahasa. Masyarakat Natuna menggunakan bahasa Melayu sebagai bahasa utama. Hal ini pula yang membuat kearifan lokal Natuna menjadi kental dalam film Jelita Sejuba. Sutradara film, Ray Nayoan mengakui bahwa film ini merupakan produksi film layar lebar pertamanya dengan mengambil unsur film yang menggambarkan nilai kearifan lokal Natuna.

Berdasarkan pada latar belakang yang dijelaskan pada bagian sebelumnya, maka penelitian ini fokus pada analisis nilai-nilai kearifan lokal yang digambarkan dalam unsur naratif dan sinematik pada proses produksi film Jelita Sejuba. Sebuah film dengan ide yang unik bertemakan drama percintaan yang dibalut dengan nuansa nilai budaya lokal. Film ini mengambil latar belakang budaya masyarakat pesisir di Pulau Natuna yaitu salah satu kabupaten di Provinsi Kepulauan Riau. Pulau Natuna dikenal dengan keindahan alamnya, bahkan Natuna dijuluki pula sebagai mutiara di ujung utara.

Kajian tentang nilai kearifan lokal selalu dinilai penting karena nilai kearifan lokal sebagai unsur keyakinan kelompok masyarakat tertentu mulai pudar, bahkan generasi selanjutnya tidak dapat mengenal dan memahami nilainilai tersebut. Kondisi ini pula yang menjadi 
tujuan utama sekaligus urgensi penelitian ini. Ketidaktahuan masyarakat tentang nilai kearifan lokal tentu saja terjadi karena berbagai faktor. Salah satunya kurangnya informasi yang diterima oleh masyarakat setempat maupun masyarakat pada umumnya. Oleh karena itu, penting kiranya adanya kerjasama antara unsur-unsur terkait, seperti pemerintah daerah setempat dengan para kreator media. Adanya kerjasama tersebut diharapkan dapat membantu mempromosikan nilai-nilai kearifan lokal di setiap daerah termasuk dalam konteks kajian ini adalah pulau Natuna.

Natuna merupakan kabupaten paling utara di Indonesia yang berada dalam wilayah Provinsi Kepulauan Riau. Wilayah Kabupaten Natuna terdiri dari dua gugusan pulau, yaitu gugusan Pulau Natuna (Bunguran, Sedanau, Midai, Pulau Laut, dan Pulau Tiga) dan gugusan Pulau Serasan (Pulau Serasan, Subi Besar, dan Subi Kecil). Berdasarkan kondisi fisiknya, Kabupaten Natuna terdiri dari tanah berbukit dan gunung batu. Daratan rendah dan landai pada umumnya terdapat di pinggiran pantai. Berdasarkan kondisi fisiknya, Kabupaten Natuna merupakan tanah berbukit dan bergunung batu. Hampir 10 persen dari wilayah Kecamatan Bunguran Timur dan Bunguran Barat merupakan daratan rendah dan landai terutama di pinggiran pantai, 65 persen berombak dan 25 persen berbukit sampai bergunung (BPS Kab. Natuna, 2017). Sebagai kabupaten paling utara, Natuna berbatasan dengan beberapa negara tetangga, yaitu Singapura, Kamboja,Vietnam, Thailand, dan Malaysia. Secara geografis, jarak Natuna dengan Malaysia (Kuching) jauh lebih dekat sekitar $350 \mathrm{KM}$ dibandingkan dengan Jakarta sekitar 1.135,628 KM (BPS Kab. Natuna, 2017).

Potensi geografis yang luar biasa, pulau Natuna dapat menjadi lokasi atau setting pengambilan gambar pada produksi film. Hal ini pula yang menjadi latar belakang sutradara memutuskan pulau Natuna sebagai salah satu unsur sinematik dalam produksi film Jelita Sejuba. Sutradara berharap kehadiran film dengan berlatar kekayaan alam Indonesia mampu membantu pemerintah dalam mempromosikan wisata Indonesia.

\section{METODE PENELITIAN}

Metode yang digunakan dalam penelitian ini adalah kuasi-kualitatif. Secara aksiologis metode ini berusaha untuk menjawab tujuan penelitian secara deskriptif. Kuasi-kualitatif sering pula disebut kualitatif semu karena berangkat dari paradigma post-positivistik. Paradigma yang secara ontologis menilai bahwa realitas adalah nyata namun tidak sempurna. Artinya ada kemungkinan hipotesis, atau data yang berubah atau adanya falsifikasi hipotesis. Penelitian kuasi-kualitatif sama halnya dengan metode kualitatif murni yang mengutamakan keterlibatan peneliti di dalamnya (Creswell, 2008). Namun yang membedakannya yakni kuasi-kualitatif berusaha untuk mengklarifikasi atau mengkonfirmasi hasil temuan dengan teoriteori. Kuasi-kualitatif tidak selalu menekankan teknik wawancara dan observasi sebagai teknik pengumpulan data. Namun, teknik data cukup melalui data sekunder dan teori-teori relevan. Kuasi-kualitatif pada umumnya tidak membangun atau menemukan teori seperti halnya pada penelitian kualitatif murni. Terkait dengan penelitian ini, data yang akan digali adalah fenomena nilai-nilai kearifan lokal yang terdapat pada film Jelita Sejuba. Dari hasil temuan tersebut, peneliti akan mencoba untuk mencocokkan atau melakukan konfirmasi terhadap teori-teori budaya dan film yang sudah ada.

Untuk menjelaskan dan menteoritisasi hasil temuan, peneliti juga menggunakan studi analisis deskriptif. Studi deskriptif menekankan pada gambaran lengkap atas fenomena yang diteliti. Studi ini bertujuan untuk mengklarifikasi fenomena berdasarkan teori relevan melalui hasil deskripsi atas sejumlah variabel atau aspek-aspek penelitian (Creswell, 2014). Penelitian deskriptif juga mencoba untuk menggali data sebanyak mungkin sesuai dengan tujuan penelitian. Dalam konteks penelitian ini, tujuannya yaitu mengetahui sekaligus mendeskripsikan nilai-nilai kearifan lokal masyarakat Natuna pada film Jelita Sejuba. Tujuan tersebut dapat diperoleh melalui analisis perencanaan produksi film meliputi unsur naratif dan unsur sinematik film. 
Pengumpulan data pada penelitian ini yaitu menggunakan teknik wawancara dan observasi. Sumber data yang terlibat dalam proses wawancara yaitu para sineas film termasuk produser dan sutradara film Jelita Sejuba, kritikus film dan penikmat film. Berdasarkan informasi yang diterima dari para sumber data (informan) tersebut peneliti melakukan analisis data meliputi beberapa tahapan yaitu reduksi, kategorisasi data, dan penarikan kesimpulan (Hidayat, Hafiar, 2018). Reduksi artinya memilih data yang dinilai sesuai serta diperlukan untuk menjawab tujuan penelitian. Tahap berikutnya pengategorisasian data; pada tahapan ini dilakukan klasifikasi data berdasarkan sub-topik yang sesuai dengan pertanyaan penelitian. Kategorisasi data berupa tabel-tabel data berkaitan dengan temuan tentang nilai-nilai kearifan lokal yang kemudian dideskripsikan pada hasil penelitian. Tahapan terakhir yaitu penarikan kesimpulan atau upaya konfirmasi data melalui teori-teori relevan atau teorisasi data. Konfirmasi teori dilakukan pada sub-bagian pembahasan hasil penelitian. Pada bagian ini penulis menguraikan secara teoritis mengenai nilai-nilai kearifan lokal yang terdapat pada film Jelita Sejuba.

\section{HASIL DAN PEMBAHASAN}

Pada awalnya peneliti melakukan observasi dari mulai trailer, video perkenalan tokoh, dan behind the scene film. Peneliti menilai bahwa film ini mampu memperkenalkan kearifan lokal Natuna dengan gamblang karena terbukti dari tata artistik dan shot-shot yang terlihat di behind the scene film tersebut. Artinya bahwa film Jelita Sejuba mampu merepresentasikan niilai-nilai kearifan lokal masyarakat Natuna yang pada hakikatnya berbudaya Melayu.

Nilai-nilai kearifan lokal pada film Jelita Sejuba dapat ditemukan pada bagian teks atau skenario film. Teks atau skenario dalam film memiliki artian yang lebih luas dari sekedar tulisan karena film juga memiliki bahasanya sendiri. Teks dapat dipahami sebagai keseluruhan dari gambar, video, desain grafis, lirik lagu, dan bisa juga dalam bentuk lain yang memiliki makna (Ida, 2014). Teks pada film disampaikan melalui bahasa audio-visual. Teks tersebut dibangun dengan memperhatikan unsur teks film yaitu naratif dan sinematik. Teks naratif merupakan naskah yang berisi tentang konten atau tema dari film Jelita Sejuba. Teks naratif film tersebut bercerita mengenai seorang istri tentara bersama lika-liku kehidupannya. Sedangkan teks sinematik menceritakan tentang teknik pengambilan gambar yang mengambil latar atau lokasi Natuna sebuah pulau dalam kawasan Kepulauan Riau yang letaknya jauh di ujung utara Indonesia. Natuna memiliki keindahan alam yang luar biasa dengan pesisir pantai yang tak kalah indahnya dari pulau lainnya di Indonesia. Teks naratif dapat dikatakan sebagai treatment sutradara pada cerita film karena naratif berhubungan dengan aspek cerita atau tema film. Setiap cerita memiliki elemen pembentuk cerita berupa tokoh, konflik, lokasi, waktu, dan lain-lain. Secara keseluruhan, aspekaspek tersebut membentuk unsur naratif yang saling berinteraksi dan berkesinambungan satu sama lain sehingga membentuk sebuah jalinan peristiwa atau cerita yang memiliki maksud dan tujuan.

Dimensi teks dalam penelitian Jelita Sejuba selain memperlihatkan unsur naratif juga unsur sinematik. Unsur ini berupa sekuensekuen yang sudah ditelaah dan diobservasi. Hasilnya terdapat 18 sekuen mengandung nilai kearifan lokal Natuna yang diambil dari keseluruhan film berdurasi kurang lebih 90 menit. Ke-18 sekuen ini dipilih berdasarkan teks sinematik. Ke-18 sekuen tersebut meliputi mise-en-scene, sinematografi, edit-ing dan suara yang digunakan di setiap sekuennya. Unsur sinematik sendiri merupakan cara atau gaya untuk mengolah unsur naratif. Dapat dikatakan unsur sinematik merupakan aspekaspek teknis pembentuk film. Sinematik dalam beberapa referensi terdiri dari empat elemen pokok, yakni mise-en-scene, suara, edit-ing, sinematografi, dan penyuntingan. Semua elemen tersebut saling berkaitan dan mendukung untuk menghasilkan sinematik yang holistik dan terintegrasi (Pratista, 2008).

Mise-en-scene dalam film Jelita Sujuba meliputi seting lokasi, kostum, tata rias, 
pencahayaan, dan akting para pemain film. Setelah dikaji peneliti menemukan bahwa film Jelita Sejuba menggambarkan potensi lokal Natuna melalui seting lokasi pengambilan gambar yang berlatar belakang pulau Natuna. Shot on location dalam film ini diilustrasikan secara apik, mulai dari kondisi pesisir dengan bebatuannya yang indah dan perumahan khas warga Natuna. Keindahan Pulau Natuna mewakili keindahan budaya dan alam Indonesia yang tidak terhingga (Suryanto, 2018). Simbol budaya lain yang terdapat di sepanjang Pulau Natuna adalah kondisi dermaga tempat para nelayan dan warung-warung tempat warga Natuna yang biasanya berjualan ikan asap.

Lokasi pengambilan gambar film berupa pesisir bebatuan, pohon kelapa berdiri tegak di sepanjang pulau Natuna tidak hanya sekedar menggambarkan simbol budaya Natuna, akan tetapi film ini mencoba untuk mendeskripsikan tentang nilai-nilai keteguhan dan prinsip hidup masyarakat Natuna yang selalu bergantung pada alam. Mereka memegang kuat ajaran atau nilai-nilai perilaku yang telah diwariskan secara organik. Salah satu perilaku yang masih dipertahankan adalah menjaga kelestarian dan keindahan pulau Natuna. "iya sampai kapanpun kita tinggalnya di sini, kita punya kewajiban untuk menjaga Natuna karena dari sini masyarakat bisa mendapatkan penghasilan." Mereka meyakini bahwa alam sebagai sumber kehidupan sehingga apabila sumber tersebut diganggu maka kestabilan hidup mereka pun akan merasa terganggu. Hal ini terbukti hingga saat ini, sebagian besar penduduk Natuna memanfaatkan pesisir sebagai sumber penghasilan mereka sebagai nelayan.

Mise-en-scene dalam film Jelita Sejuba juga terukur melalui tata rias pemain. Riasan dibuat senatural mungkin sehingga mampu merepresentasikan sosok gadis desa Natuna yang cantik jelita karena keasliannya, bukan karena make-up dan gemerlap perhiasan yang digunakan, akan tetapi kecantikan yang lahir dari keluhuran pribadi. Kecantikan gadis desa Natuna juga diilustrasikan seperti halnya keindahan Pulau Natuna yang disebut Sejuba. Rias yang dimaksud pada film ini adalah rias pada sosok Sharifah yang menjadi pusat perhatian sebagai tokoh utama film. Simbol kecantikan yang diperlihatkan oleh Sharifahjuga menggambarkan tentang keaslian masyarakat Natuna. Mereka berkeyakinan bahwa sikap dan perilaku seseorang harus mencerminkan kejujuran dan ketulusan. Kejujuran tidak perlu direkayasa karena kejujuran berawal dari hati. Apabila kejujuran dilebih-lebihkan akan berubah menjadi kebohongan. Nilainilai ini pula yang sebenarnya dipertahankan masyarakat Natuna, seperti layaknya mereka menjaga kelestarian alam pulau Natuna.

Mise-en-scene dalam film Jelita Sujuba juga terlihat dari kostum yang dikenakan para pemain yang ikut berkontribusi terhadap kondisi kelokalan warga Natuna. Kostum laki-laki maupun perempuan tersebut seakanakan mengatakan bahwa masyarakat Natuna adalah masyarakat berbudaya Melayu. Hal ini terlihat dari kostum laki-laki dengan berbalut baju tangan panjang tanpa kerah yang dipadupadankan dengan sarung pendek setinggi lutut. Pakaian ini memiliki kesamaan dengan pakaian laki-laki masyarakat adat Saibatin Lampung. Mereka menyebut sarung pendek tersebut dengan istilah "bulipat" (Hidayat et al., 2018). Demikian halnya dengan kostum perempuan, mereka menggunakan baju panjang bertutup kepala yang disebut "kumbut" atau bahasa populernya adalah kerudung.

Pakaian yang digunakan para pemain film Jelita Sejuba, tidak hanya ingin menunjukkan jenis dan bentuk dari pakaian sebagai simbol budaya masyarakat Melayu. Akan tetapi, sutradara film juga bermaksud untuk menyampaikan nilai-nilai moral yang hingga kini dipegang teguh oleh masyarakat Melayu Natuna. Mereka berkeyakinan bahwa pakaian yang mereka kenakan mengandung nilai bahwa dengan berpakaian yang sopan mereka telah berusaha menutup malu. Artinya bahwa pakaian tidak hanya sekedar untuk keindahan dan kenyamanan, akan tetapi digunakan untuk penutup aurat laki-laki maupun perempuan. Hal ini dapat dijumpai pada pakaian yang dikenakan oleh para pemain yang mencerminkan pribadi orang Melayu dengan berpakaian serba tertutup tanpa memperlihatkan aurat. Pakaian sebagai simbol budaya juga menegaskan 


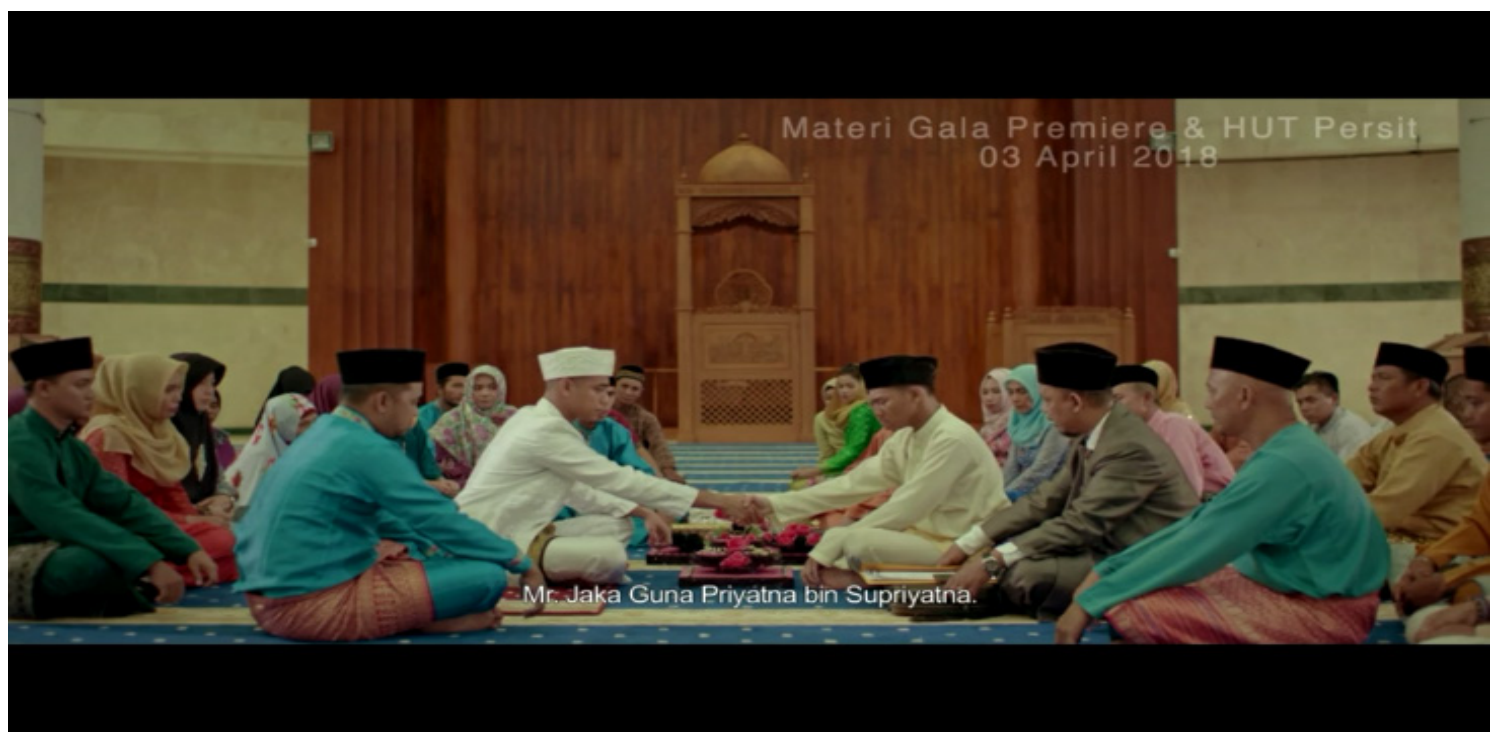

Sumber: Gala Premiere, 2018

\section{Gambar 1 Sekuen 11 Ijab Kabul}

bahwa masyarakat Natuna adalah masyarakat yang menjunjung tinggi nilai-nilai agama, dan ketaatan sudah menjadi bagian atau mengkristal di dalam sendi kehidupan masyarakat Melayu Natuna. Melayu memang dikenal sebagai masyarakat yang religius atau masyarakat yang kental menerapkan nilai-nilai agama dalam berperilaku (Alfarabi, Venus, Syafirah, \& Salam, 2019). Filosofi lain dari simbol pakaian Melayu yang terdapat pada film Jelita Sejuba yaitu menggambarkan bahwa masyarakat Natuna sangat memegang teguh nilai-nilai budi pekerti dan karakter. Hal ini dapat dibangun dan dimulai dari adab atau tata-cara berpakaian. Menurut para informan bahwa cara berpakaian seseorang mencerminkan kepribadiannya. Oleh karena itu, dengan pakaian yang menutup aurat diharapkan masyarakat Natuna memiliki akhlak mulia.

Dengan segala kelebihan yang dicapai dari segi mise-en-scene ternyata sutradara juga mencoba untuk memberikan pesan moral tentang tokoh pemuda yang kurang fasih dalam berbahasa Melayu. Tokoh tersebut adalah Farhan sebagai lawan main Sharifah. Pada sekuen 11 atau adegan ijab qabul pernikahan antara Farhan dengan Sharifah, Farhan berakting sebagai pemuda Melayu, namun cara berbicaranya tidak mencerminkan cengkok Melayu. Hal ini berbeda dengan tokoh lainnya seperti Sharifah, ibu, bapak, bahkan sahabat- sahabat Sharifah yang memang memerankan masyarakat Natuna dengan cengkok Melayu yang kental. Tokoh Farhan ini merupakan teks yang menggambarkan kondisi miris dari salah satu sisi gelap Natuna yang ternyata memiliki beberapa anak muda yang kondisi pergaulannya sangat memprihatinkan. Anak muda Natuna yang mulai meninggalkan bahasa daerah yang semestinya dijaga dan dilestarikan. Minimnya pengetahuan anak muda Natuna terhadap bahasa Melayu salah satu faktornya dikarenakan pengaruh globalisasi yang telah melahirkan sikap skeptis (Karnanta, 2012). Sikap yang dapat merusak rasa percaya diri anak muda Natuna terhadap penggunaan bahasa leluhurnya.

Bahasa Melayu diangkat dalam salah satu bagian film Jelita Sejuba karena bahasa merupakan salah satu identitas masyarakat Melayu (Alfarabi, Syarifah, Salam, 2019). Khususnya masyarakat Natuna berkeyakinan bahwa bahasa ibu tetap harus dijunjung tinggi. Menurut informan bahwa bahasa yang mereka gunakan sebagai ciri khas dari bahasa daerah lainnya. Demikian pula pendapat Samovar bahwa bahasa sebagai salah satu parameter untuk mengenali budaya orang lain (Samovar, Porter, \& McDaniel, 2010).

Selain mise-en-scene, aspek lain yang menonjol adalah sinematografi. Dalam film Jelita Sejuba diketahui bahwa dari segi 
senematik terdapat 31 menit 16 detik dari scene yang mengandung nilai kearifan lokal Natuna. Namun, sangat disayangkan mengingat film ini mengambil shot on location di Natuna yang semestinya masih dapat dioptimalkan kembali scene kearifan lokalnya. Sinematografi mencakup perlakuan sineas terhadap kamera serta stok filmnya (Pratista, 2008). Seorang sineas tidak hanya sekedar merekam sebuah adegan semata, namun juga harus mengontrol dan mengatur bagaimana adegan tersebut diambil, seperti jarak, ketinggian, sudut, lama pengambilan dan sebagainya.

Dalam teknik pengambilan gambar atau sinematografi, kamera merupakan alat yang berpengaruh terhadap kualitas gambar. Secara umum terdapat dua pemilihan alat perekam visual dalam produksi film, yakni kamera film dan kamera digital. Dewasa ini sudah jarang sekali produksi film menggunakan kamera film dengan pita seluloid karena dalam produksinya akan cukup riskan dan tidak efisien. Kebanyakan dari sineas saat ini menggunakan kamera digital yang lebih mudah digunakan dan tidak terlalu berisiko. Dalam hal ini juga termasuk pada pemilihan lensa dan pengaturan tone atau warna pada kamera.

Teknik sinematografi juga berkaitan dengan teknik framing yaitu bagaimana sineas menggunakan teknik pengambilan gambar seperti jarak, sudut, kemiringan, juga ketinggian kamera terhadap objek. Framing meliputi durasi gambar. Terdapat dua jenis durasi dalam film yakni durasi shot dan durasi cerita. Durasi shot dapat diatur sesuai dengan kebutuhan. Misalnya dalam adegan perkelahian biasanya menggunakan slow motion untuk mendramatisir adegan pukulan atau tendangan atau dalam menjelaskan bahwa hari sudah berganti-ganti atau sudah berganti musim bisa menggunakan fast motion. Selain itu ada yang disebut dengan long take atau take adegan yang cukup lama lebih dari 9-10 detik. Semua itu bergantung pada seni sinematik masing-masing sineas. Seni identik dengan kreativitas sineas dalam memproduksi film. Seni pula dinilai sebagai bagian dari totalitas kerja dengan maksud mendapatkan hasil yang maksimal (Rukmi \& Lakoro, 2012). Demikian pula teknik sinematografi sebagai seni berusaha untuk menghasilkan gambar yang sesuai dengan kebutuhan cerita dalam film Jelita Sejuba.

Footage yang bertebaran diseluruh film Jelita Sejuba merupakan salah satu seni dan teknik sinematografi yang digunakan untuk menutupikurangoptimalnyaaspek kearifanlokal dalam film ini. Footage-footage yang menjadi atmosfer diantaranya spot wisata bebatuan yang menjulang tinggi di Pulau Natuna. Footagefootage (visul audio) merupakan inisiatif kreatif dalam mensiasati gambar bergerak terdiri dari sekumpulan gambar dan disertai oleh audio (Baron, 2012). Footage dapat dikatakan sebagai keharusan dalam teknik sinematografi yang bertujuan untuk melengkapi konten di dalam alur cerita film.

Spot bebatuan memang mendominasi unsur sinematik. Adegan-adegan dengan

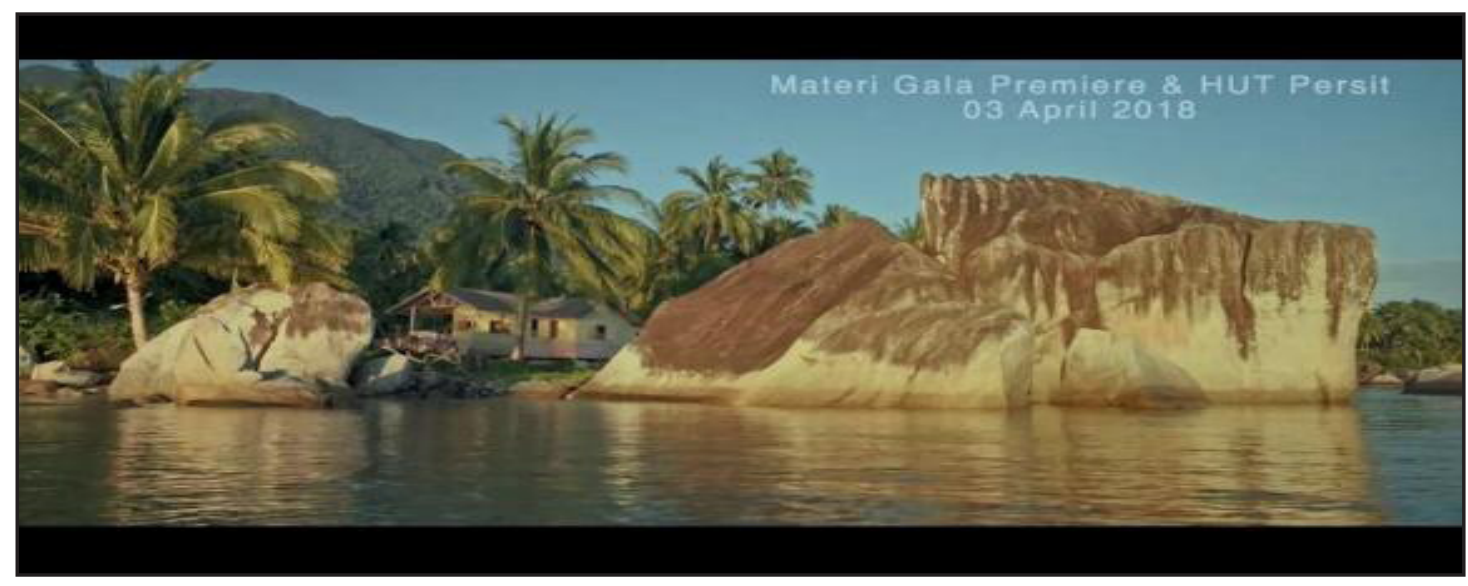

Sumber: Gala Premiere, 2018

Gambar 2 Sekuen spot wisata bebatuan Pulau Natuna 


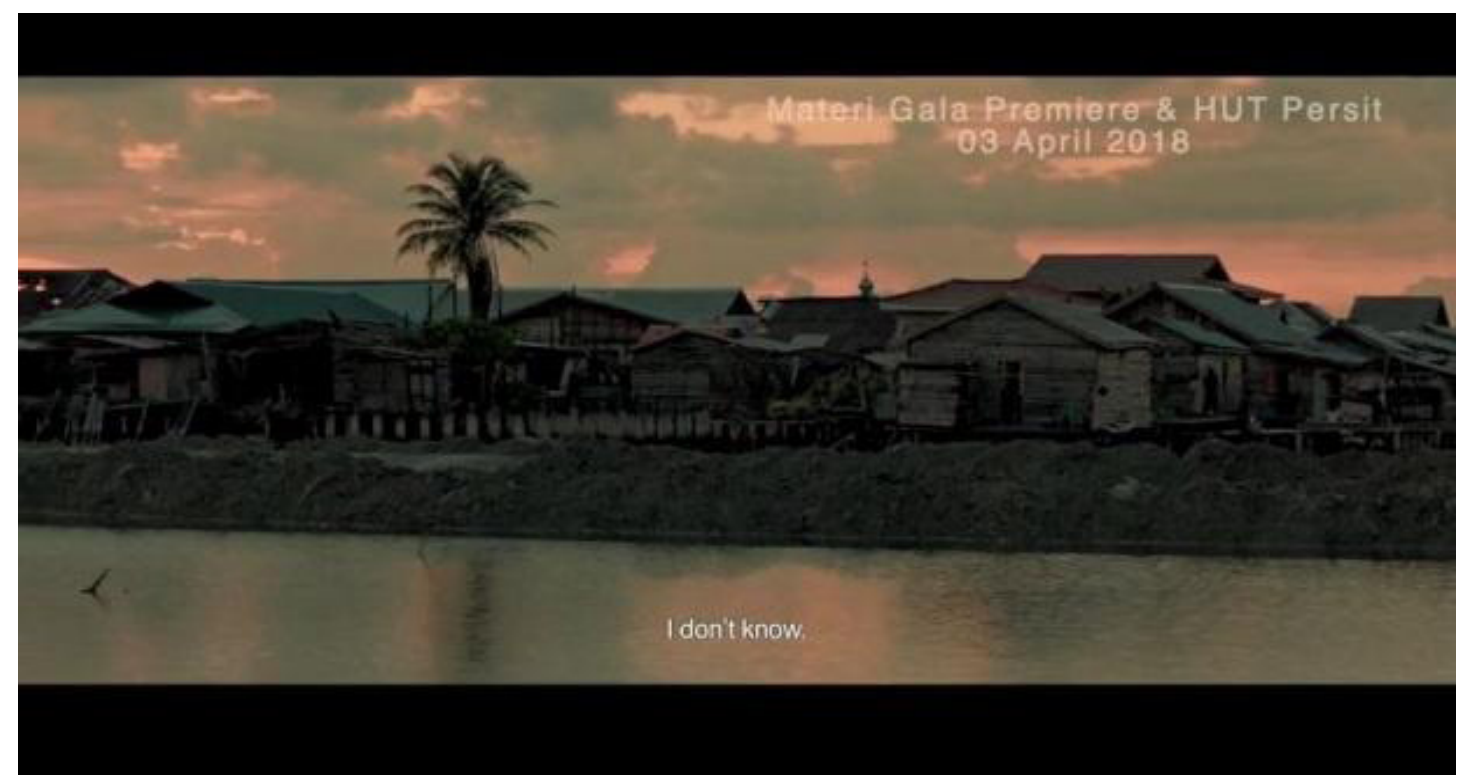

Sumber: Gala Premiere, 2018

Gambar 3 Sekuen spot wisata rumah masyarakat Natuna

latar keindahan bebatuan bertujuan untuk memperkenalkan pesona Pulau Natuna. Spot bebatuan berukuran besar yang digambarkan pada film tersebut menjadi daya tarik penonton untuk berkunjung ke Pulau Natuna. Bebatuan selain sebagai simbol budaya Pulau Natuna, akan tetapi juga menggambarkan prinsip masyarakat Natuna yang teguh dalam melestarikan nilai-nilai leluhur yang sifatnya diturunkan atau organik. Mereka berusaha tetap menonjolkan nilai-nilai kearifan lokal di tengah situasi globalisasi.

Selain bebatuan sebagai simbol budaya Pulau Natuna, unsur sinematik film Jelita Sejuba juga menghadirkan suasana pantai dengan didominasi oleh pohon kelapa sebagai tumbuhan yang ada di sekitar pesisir Natuna. Hal ini tentu saja menjadi salah satu alternatif atmosfer lainnya untuk menggambarkan nilainilai keindahan pulau Natuna. Di samping itu juga ingin menggambarkan identitas pulau yang masih alami dengan adanya pohon kelapa. Tidak hanya itu saja, bahwa bentuk pohon kelapa yang tegak lurus juga menceritakan nilai-nilai kearifan lokal masyarakat Natuna yang memiliki cita-cita luhur, bersih, dan berusaha untuk tidak mengambil jalan yang salah atau berbelok dari jalan kebaikan dalam menggapai tujuan. Nilai ini sesuai pula dengan prinsip hidup masyarakat Melayu Natuna yang senantiasa berpedoman pada ajaran agama Islam.

Film Jelita Sejuba juga mencoba untuk menampilkan atmosfir kearifan lokal melalui tempat tinggal khas masyarakat pesisir Natuna. Meskipun atmosfir tersebut tidak mendominasi, akan tetapi bangunan khas Natuna juga mampu mencuri perhatian penonton. Hal ini terbukti ketika penonton mampu mendeskripsikan tentang bentuk bangunan masyarakat Natuna. Rumah tidak saja melukiskan tentang simbol tempat tinggal masyarakat Natuna, akan tetapi menceritakan pula tentang nilai-nilai kearifan lokal Natuna yang penduduknya sangat dekat dan bersahabat dengan alam sekitar. Keteguhan masyarakat Natuna memiliki alasan yaitu untuk mengenalkan pada tiap generasi bahwa masyarakat Natuna memiliki simbol kebanggaan berupa rumah khas atau bisa disebut sebagai rumah adat.

Unsur lain yang menggambarkan nilai budaya yaitu hampir semua lagu atau music scoring dalam film Jelita Sejuba membangkitkan atmosfir Natuna yang kental akan musik Melayu. Meskipun terdapat satu lagu yang menjadi official soundtrack dinilai para kritikus film kurang pas dengan taste Melayu. Bagi para penikmat film musik adalah salah satu alasan bahwa film Jelita Sejuba merupakan film yang secara unsur naratif dan sinematik menawarkan tentang nilai-nilai kearifan lokal Natuna. 
Nilai budaya yang digambarkan pada musik film juga mempertegas tentang nilainilai kearifan lokal masyarakat Natuna yang sangat mencintai musik daerah Melayu. Mereka berprinsip bahwa musik maupun lagu Melayu mengandung nilai-nilai luhur dan nilai kebaikan. Berbeda terbalik dengan lagu atau musik modern yang seringkali tidak menonjolkan nilai-nilai positif. Misalnya saja lagu "soleram anak yang manis" sebagai lagu pengantar tidur, dan menceritakan tentang harapan seorang ibu untuk anaknya agar menjadi anak yang dapat menjaga kehormatan dan menjaga malu sebagai budayanya.

Setelah menelaah, memperhatikan berbagai aspek sinematis yang ada pada final cut film Jelita Sejuba, peneliti menemukan pula bahwa proses editing film Jelita Sejuba memang menonjolkan kearifan lokal, meskipun upaya tersebut kurang berhasil dalam pengolahannya. Penempatan scene demi scene atau pembabakan atau dapat disebut penyusunan plot terkesan monoton sehingga berpengaruh baik secara naratif maupun sinematik pada film ini. Tidak ada keistimewaan transisi atau aspek editing sehingga unsur kearifan lokalnya belum maksimal seperti versi director's cut dari film ini. Editing merupakan bagian dari sinematik film. Editing dilakukan setelah proses pengambilan gambar selesai. Editing memiliki peran yang besar dalam produksi film. Sejak awal perkembangan sinema, para sineas telah menyadari betapa kuatnya pengaruh teknik editing untuk memanipulasi ruang dan waktu (Pratista, 2008). Dapat dikatakan bahwa dengan editing sutradara dapat membuat segala sesuatu menjadi mungkin pada sebuah film.

Editing meliputi transisi shot yang pada umumnya dilakukan dalam empat bentuk, yakni fade-in/out, cut, wipe, dan dissolve (Pratista, 2008). Bentuk-bentuk editing tersebut mempengaruhi sebuah film dalam menuturkan ceritanya, seperti memberi beberapa efek dramatis atau demi menggambarkan suatu kondisi. Bentuk editing yang paling umum digunakan oleh editor biasanya adalah cut, yakni transisi shot secara langsung. Hal lain yang perlu diperhatikan pada editing yaitu pendekatan kontinuitas grafik yakni kesamaan pada gambar baik dari posisi pemain atau komposisi properti dalam frame. Untuk membuat visual yang 'rapi' beberapa sineas melakukan kontinuitas grafik dalam beberapa adegan atau bahkan seluruh shot pada film. Selain itu juga ada aspek ritmik atau ritme dalam bentuk durasi shot dalam film, misalnya dalam film aksi biasanya shotshot terhitung pendek untuk menunjukan pergerakan karakter. Aspek spasial juga tak kalah penting dalam editing, aspek spasial disini memungkinkan seorang editor menggabungkan beberapa shot yang berbeda motivasinya untuk memberikan cerita yang baru (Pratista, 2008).

Analisis lainnya yang dipaparkan atas hasil temuan pada film Jelita Sejuba yaitu dimensi discourse practice atau dimensi kewacanaan dalam Jelita Sejuba meliputi produksi dan konsumsi film Jelita Sejuba. Dalam produksi film Jelita Sejuba, seperti pada film umumnya mengandalkan triangle system yakni produser, sutradara, dan penulis skenario. Merka bekerja sama membentuk perencaraan produksi film, mulai dari cerita, pembabakan, memilih set lokasi, hingga pendanaan. Tahapan kerja tersebut merupakan bagian dari pra-produksi, produksi dan pasca-produksi(Saptya et al., 2018).

Nuansa kearifan lokal pada film Jelita Sejuba juga dapat ditemukan pada ide ceritanya. Alur cerita sangat dipengaruhi oleh situasi dan pengalaman pribadi dari salah seorang penduduk pribumi Natuna. Dipilihnya daerah Natuna, secara otomatis akan mempermudah atmosfer Natuna sebagai setting lokasi. Ray Nayoan sebagai sutradara film melihat potensi alam Natuna sebagai nilai tambah dalam filmnya. Pengalaman sutradara saat observasi membuat sutradara tergerak untuk mengangkat kearifan lokal Natuna agar dapat lebih dikenal luas oleh masyarakat Indonesia. Ray Nayoan begitu terpukau dengan kearifan lokal Natuna baik dari segi geografis maupun demografis. Menurut Ray, Natuna seperti harta karun dari beautiful shot. Natuna dengan kondisi yang masih natural dengan pesisir pantai yang bersih serta hamparan batu-batu besar yang menawan. Ray Nayoan merasa hal tersebut dapat menjadi kekuatan tersendiri untuk film Jelita Sejuba. Untuk mewujudkan keinginan tersebut Ray 
mengoptimalkan potensi yang ada melalui kolaborasi dengan sanggar Natuna.

Ide cerita film Jelita Sejuba juga dilatar belakangi oleh keinginan kuat sutradara untuk memperkenalkan Natuna yang hingga saat ini belum dikenal secara umum. Yakni pulau yang memiliki penduduk berbudaya Melayu dan masih menjunjung nilai-nilai ketimuran. Dalam film ini, tokoh Sharifah digambarkan sebagai sosok jelita atau wanita yang memiliki keteguhan hati layaknya batu-batu indah dan kokoh yang menghiasi pesisir sejuba. Selain Sharifah, situasi sosial lainnya yang diangkat adalah konflik tokoh Farhan yang menggambarkan anak muda Natuna yang mulai meninggalkan nilai-nilai budaya Natuna, seperti penggunaan bahasa Melayu.

Situasi sosial yang ingin diangkat dalam film ini sedemikian kompleks dan memang memiliki atmosfer yang layak diangkat dalam layar lebar. Ray sebagai sutradara memang ingin menggugah penonton bahwa masih ada daerah di Indonesia yang jauh di perbatasan, namun memiliki kehidupan dan budaya yang khas. Situasi ini sekaligus menjelaskan bahwa budaya Melayu merupakan bagian dari budaya Natuna sekaligus khasanah budaya Indonesia.

Pengambilan judul Jelita Sejuba awalnya mengundang pro dan kontra, meskipun pada akhirnya judul tersebut disepakati. Adapun filosofi yang terkandung dari makna Jelita yaitu mewakili gadis Melayu yang cantik rupa, cantik tutur kata dan sikap ketimuran yang dijunjung tinggi oleh orang-orang Melayu. Jelita juga mengandung maksud untuk menyadarkan khalayak dari imperialisme budaya barat yang sudah mulai menggeser nilai ketimuran bangsa Indonesia.

Film Jelita Sejuba dapat dinikmati oleh penonton melalui bioskop di seluruh tanah air secara serentak mulai tanggal 5 April 2018. Namun, meskipun bioskop memiliki jangkauan serentak, akan tetapi seperti kita ketahui bioskop tidak menyebar rata sampai ke daerahdaerah tertentu. Hal ini menjadikan cakupan penonton Jelita Sejuba terbatas, ditambah lagi pihak bioskop yang tidak banyak memberikan layar bagi Jelita Sejuba. Faktor penghambat lainnya bahwa penyebaran film Jelita Sejuba atau promosi dinilai rendah sehingga membuat film ini kurang dikenal khalayak. Namun hadirnya bioskop-bioskop indie di berbagai kota yang biasanya masih menayangkan film-film Indonesia yang sudah tidak tayang di bioskop sangat membantu dalam penyebaran film ini.

Hadirnya film Jelita Sejuba di tengahtengah perfilman Indonesia pada akhirnya menjadi bagian dari media komunikasi. Film Jelita Sejuba sebagai media komunikasi massa berhasil meraup kurang lebih 103.466 penonton. Belum maksimalnya jumlah penonton karena dipengaruhi oleh faktor nonteknis dan teknis seperti adanya perubahan editing dan music scoring yang menyebabkan kearifan lokal dalam final cut tidak sekental pada director cutnya. Selain itu, film ini tidak disokong oleh institusi terkait yang awalnya dianggap akan membantu dalam pemasaran, namun ternyata tidak. Penarikan dukungan ini karena film tersebut dinilai tidak mewakili image institusi tertentu. Hal ini menjadikan posisi film Jelita Sejuba tidak terangkat sehingga akhirnya konsumsi film Jelita Sejuba digeser oleh film super hero hollywood. Dalam kasus yang sama pada tahun 2017, film-film bernuansa kearifan lokal seperti Marlina; si Pembunuh dalam Empat Babak, juga sepi penonton. Padahal film Marlina telah mendapatkan berbagai penghargaan di festival internasional. Namun, penghargaan tersebut ternyata tidak menjamin film dengan konteks kearifan lokal yang sangat apik ini diminati oleh khalayak Indonesia. Kurangnya kepedulian masyarakat Indonesia pada akhirnya juga mempengaruhi film dengan konten kearifan lokal di pasaran kurang eksis jika dibandingkan dengan film hollywood. Padahal konten film lokal sangat layak untuk diperkenalkan di dunia internasional. Upaya ini salah satu kontribusi para sineas dalam membangun citra tentang film Indonesia. Citra dapat diartikan sebagai penilaian atau kesan publik (Hidayat et al., 2017). Citra yang dimaksud pada penelitian ini adalah kesan masyarakat dunia terhadap nilainilai budaya Indonesia yang dikenal melalui ide cerita film. Kesan positif yang terbangun di masyarakat tentu saja sangat membantu terbangunnya kepercayaan masyarakat terhadap film Indonesia. 


\section{SIMPULAN}

Film Jelita Sejuba berhasil menggambarkan tentang nilai-nilai kearifan lokal masyarakat Natuna. Nilai-nilai tersebut terdapat pada hampir semua alur cerita dan teknik pengambilan gambar (sinematografi) yang terdapat pada unsur naratif dan unsur sinematik film. Unsur naratif menceritakan tentang ide cerita maupun penokohan yang memerankan masyarakat Natuna dengan kekhasan budaya Melayu, meliputi keindahan alam pesisir Natuna, bahasa, pakaian, tata rias, dan musik.

Lokasi pengambilan gambar film berupa pesisir bebatuan, pohon kelapa berdiri tegak di sepanjang pulau Natuna tidak hanya sekedar menggambarkan simbol budaya Natuna, akan tetapi film ini mencoba untuk mendeskripsikan tentang nilai-nilai keteguhan dan prinsip hidup masyarakat Natuna yang selalu bergantung pada alam. Mereka memegang kuat ajaran atau nilai-nilai perilaku yang telah diwariskan secara organik. Salah satu perilaku yang masih dipertahankan adalah menjaga kelestarian dan keindahan pulau Natuna. Mereka meyakini bahwa alam sebagai sumber kehidupan sehingga apabila sumber tersebut diganggu maka kestabilan hidup mereka pun akan merasa terganggu.

Pakaian yang digunakan para pemain film Jelita Sejuba, tidak hanya ingin menunjukkan jenis dan bentuk dari pakaian masyarakat Melayu, akan tetapi sutradara film juga bermaksud untuk menyampaikan nilai-nilai moral yang hingga kini dipegang teguh oleh masyarakat Natuna. Mereka berkeyakinan bahwa pakaian yang mereka kenakan mengandung nilai bahwa dengan berpakaian yang sopan mereka telah berusaha menutup malu. Artinya bahwa pakaian tidak hanya sekedar untuk keindahan dan kenyamanan, akan tetapi digunakan untuk penutup aurat laki-laki maupun perempuan. Filosofi lain dari simbol pakaian Melayu yang terdapat pada film Jelita Sejuba yaitu menggambarkan bahwa masyarakat Natuna sangat memegang teguh nilai-nilai agama, budi pekerti, dan karakter.

Bahasa Melayu juga diangkat dalam salah satu bagian film Jelita Sejuba karena bahasa merupakan salah satu identitas masyarakat Melayu. Khususnya masyarakat Natuna berkeyakinan bahwa bahasa ibu tetap harus dijunjung tinggi. Bahasa sebagai ciri khas dari bahasa daerah lainnya. Filosofi lainnya yang terdapat pada film ini adalah tentang keyakinan terhadap musik maupun lagu Melayu yang dinilai mengandung nilai-nilai luhur dan nilai kebaikan di tiap liriknya.

Terlepas dari keberhasilan sutradara dalam mengangkat nilai-nilai kearifan lokal Natuna, akan tetapi disisi lain ada kelemahannya yaitu dalam segi keberlangsungan film tersebut. Film Jelita Sejuba tercatat hanya bertahan sebentar dan posisinya langsung tergantikan oleh film lain termasuk film-film hollywood. Kondisi ini semestinya menjadi perhatian pemerintah agar lebih memperhatikan film-film Indonesia khususnya ide cerita film yang mengangkat tentang nilai budaya dan nilai kearifan lokal sebagai kekayaan budaya Indonesia.

Kelemahan lainnya dari film Jelita Sejuba yaitu unsur naratif maupun sinematik belum secara gamblang merepresentasikan nilainilai kearifan lokal. Akan tetapi baru pada penggambaran simbol dan konteks budaya masyarakat Natuna. Untuk itu, perlu adanya pendalaman karakter dengan melibatkan masyarakat lokal dalam waktu yang cukup lama.

Terlepas dari kelebihan dan kekurangan, melalui film ini diharapkan mampu membantu proses sosialisasi budaya sebagai destinasi wisata domestik maupun mancanegara. Ada baiknya pemerintah melalui institusi terkait mengeluarkan kebijakan tentang porsi tayang yang lebih proporsional. Kebijakan ini jangan sampai dikalahkan oleh kepentingan ekonomi sekelompok orang. Sebaliknya bahwa adanya kebijakan yang mengikat antara pemerintah dengan pelaku industri film akan membantu ekonomi bangsa Indonesia menyusul meningkatnya pengetahuan dan kepercayaan masyarakat terhadap Indonesia yang menawarkan destinasi wisata melalui ide cerita di setiap film yang diproduksi. 


\section{DAFTAR PUSTAKA}

Alfarabi, Venus, A., Syafirah, N. A., \& Salam, N. E. (2019). Media identitas Melayu pascareformasi di Indonesia. International Journal of Multicultural and Mutireligious Understanding, 6(1), 21-31.

Badan Pusat Statistik Kab. Natuna. (2017).

Baksin, A. (2003). Membuat film indie itu gampang. Bandung: Katarsis.

Baron, J. (2012). The archive effect: archival footage as an experience of reception. Projections, 6(2), 102-120. DOI: http://doi.org/10.3167/ proj.2012.060207.

Creswell, J. W. (2008). The use of theory. SAGE Publication.

Creswell, J. W. (2014). Research design pendekatan kualitatif, kuantitatif, dan mixed. Yogyakarta: Pustaka Pelajar.

Hidayat, D., \& Hafiar, H. (2019). Nilai-nilai budaya soméah pada perilaku komunikasi masyarakat Suku Sunda. Jurnal Kajian Komunikasi, 7(1), 84-96.

Hidayat, D., Kuswarno, E., Zubair, F., \& Hafiar, H. (2018). Public relations communication behavior through a local-wisdom approach: the findings of public relations components via ethnography as methodology. Malaysian Journal of Communication, 34(3), 56-72.

Hidayat, D., Kuswarno, E., Zubair, F., Hafiar, H., Bina, U., Informatika, S., \& Padjadjaran, U. (2017). Message platform atribut siger Lampung di dalam kebhinekaan multikultur. Jurnal Kajian Komunikasi, 5(1), 91-101. DOI: https://doi.org/10.24198/jkk.v5i1.9481.

Ida, R. (2014). Metode penelitian studi media dan kajian budaya. Jakarta: Prenada Media Grup.

Karnanta, K. Y. (2012). Ekonomi politik film dokumenter indonesia dependensi film dokumenter Indonesia kepada Lembaga Donor
Asing (Vol. 1).

Munanjar, A. (2016). Analisis wacana Van Dijk tentang realitas beda agama pada film $\operatorname{Cin}(\mathrm{T}) \mathrm{a}$. Jurnal Komunikasi, VII, 1-6.

Noviani, R. (2011). Konsep diri remaja dalam film Indonesia: analisis wacana atas film remaja Indonesia tahun 1970-2000-an. Jurnal Kawistara, 1(1), 40-54. DOI: http://doi. org/10.22146/kawistara.3905.

Pakaradena, A., Hafiar, H., Nugraha, A. R., Studi, P., Masyarakat, H., Komunikasi, F. I., \& Padjadjaran, U. (2018). Proses public relations dalam program Layar Tancap Untuk Semua oleh SCTV. Pro TVF, 2(September).

Pratista, H. (2008). Memahami film. Yogyakarta: Homerian Pustaka.

Rukmi, P., \& Lakoro, R. (2012). Perancangan concept art game berlatar budaya Majapahit sebagai media komunikasi. Sains Dan Seni, $1(1), 1-5$.

Samovar, L. A., Porter, R. E., \& McDaniel, E. R. (2010). Komunikasi lintas budaya; communication between cultures (7th ed.). Jakarta: Salemba Humanika. Diakses dari http://www.penerbitsalemba.com.

Saptya, R., Permana, M., Puspitasari, L., \& Indriani, S. S. (2018). Strategi promosi pada tahapan pra-produksi film haji asrama (HAS). ProTVF, 2(September).

Suryanto, H. (2018). Film as cultural diplomation assets. Capture, 9(2), 47-55. DOI: http://doi. org/10.33153/capture.v9i2.2089.

Susilowati, E., Dhanang, R., \& Noor, N. (2014). Penanaman nilai-nilai nasionalisme pada generasi muda di Kepulauan Natuna. Humanika, 19(1), 158-170.

Vajdovich, G. (2019). National identity in Hungarian cinema between 1929 and 1947. Studies in Eastern European Cinema, 3518. DOI: http:// doi.org/10.1080/2040350X.2018.1556560. 